\title{
The Study of Concentration Cow Biourine and Dosage of SP-36 Fertilizeron Growth and Production of Soybean
}

\author{
MariyatulQibtiyah \\ (Faculty of Agrotechnology, University of Islam DarulUlumLamongan, East Java-Indonesia)
}

\begin{abstract}
The purpose of this study was to determine the influence of concentration cow biourine and SP-36 fertilizer application on the growth and production of soybean (Glycine max (L.) Merrill). The research was conducted in the village of KarangSambigalihSugiosubdistrict, Lamongan, East Java, Indonesia. The study used a randomized block design (RAK) factorial design with three replications, consisting of two factors: the concentration of cattle biourine $(B)$ and fertilizer SP-36 (P). Concentration factor of cow biourine consisted of three levels: the concentration of cattle biourine 1: 5 (B1), the concentration of cattle biourine 1: $10(B 2)$, without biourine (B3). Factors kinds of fertilizers SP-36 consists of three levels: Without fertilizer SP-36 (P1), $S P-36$ fertilizer $100 \mathrm{~kg} \mathrm{ha}^{-1}(P 2)$ and SP-36 fertilizer $125 \mathrm{~kg} \mathrm{ha}^{-1}(P 3)$. Indicators of growth and production observed included: plant height, leaf area index, plant dry weight, the weight of the wet pod, pod dry weight and dry weight of 1000 seeds per experimental plot. Observations carried out from the age of 21 days with an interval of 14 days. Data results of observations were analyzed by analysis of variance followed by LSD test $5 \%$. From the observations and calculations by analysis of variance can be concluded that giving production of high or better than the other treatments, the treatment with cow biourine concentration of 1: 5 and SP-36 fertilizer $125 \mathrm{~kg} \mathrm{ha}^{-1}$.
\end{abstract}

Keywords: Biourine Plus Beef, Soybeans, Increased Production

\section{Introduction}

In Indonesia, soybean is the main raw material of food processing industry. Approximately $94 \%$ utilization of Indonesian soy used for the manufacture of foodstuffs, both fermented back as Tempe, Oncom, Tauco, Ketchup or unfermented back as tofu, soy milk, soybean oil or snack (Swastika, Marwanto and Simatupang 2005).

In 2014, CPM noted that soybean production increased by $22.3 \%$ to reach 953960 tonnes of dry beans compared to 2013 which only reached 779990 tonnes, but this figure is still less than soybean imports amounted to 1.58 million tons, thus the need for increased productivity soy to reduce soybean imports. Efforts to improve the productivity of soybean plants can be done in many ways, one of which is fertilization. The use of inorganic fertilizers constantly and excessively is not matched by the use of organic fertilizers caused the soil becomes hard and long productivity will decline over time. So the use of inorganic fertilizers should start to be reduced and offset by using organic fertilizers.

Cow Biourine is one of alternatives to liquid organic fertilizer through a fermentation process to increase the availability of nutrients for plants containing micro-organisms. So as to reduce the use of inorganic fertilizer $(\mathrm{N}, \mathrm{P}, \mathrm{K})$, and increase crop yields to the maximum. The presence of organic material in cow biourine able to improve physical, chemical, and biological soil (Sutari, 2010). Determination of concentration biourine and water is essential to provide exact composition of organic nutrients to increase crop production

Nutrient management is one of the important factors for the growth of soybeans. In dry land reported planting soybean plants respond quite well to the addition of phosphorus. Currently farmers use SP-36 fertilizer for soybean crops amounts range 50-100 $\mathrm{kg} \mathrm{ha}^{-1}$. Phosphorus (P) is a plant macro nutrients that are essential for plant growth, because it is a structural component that can not be substituted. Disadvantages element $(\mathrm{P})$ may be showing signs of declining SINTESI protein, such as slow seeds and leaves of purple (Adisarwanto, 2008).

\section{Material and Method}

This research was conducted in the village of Karang Sambigalih District of Sugio, elevation of 10.4 meters above sea level. When the study in January 2015 until April 2015. The material used in this study are: soybean seed varieties Willis, cow dung, cow urine, water, EM 4, molasses (sugar drops), SP-36 fertilizer, urea, $\mathrm{KCl}$. The tools used are: Hoe, drill, tape measure, scales, nameplate, marker, buckets, raffia, plastic drums, mixer, sprayer and stationery. Biourine cow made with the composition: 2 liters of cow urine, cow solid impurities $5 \mathrm{~kg}, 501$ of water, and 11 of EM 4, $250 \mathrm{ml}$ of molasses. Ways of making: All material is inserted into the drum and left for two weeks in a closed state, opened and stirred every day for 15 minutes. After 2 weeks biourine cow ready to be used with water added in accordance with the treatment concentration. 
Applications biourine and SP-36 is Cow Biourine applied by spraying on plant leaves that served as the plant aged 14 and 28 days after planting. Cow Biourine provided with a wide range of concentrations is 1: 5,1 : 10 and without biourine.The given of SP-36 fertilizer at planting time and age 14 days after planting at a dose that is without SP-36, $100 \mathrm{~kg} \mathrm{ha}^{-1}, 125 \mathrm{~kg}$ Judge 1.

Observations were made to determine the effect of each treatment. Observations vegetative phase is done when the plant was 21 days, indicators of growth and production observed included: plant height, leaf area index, plant dry weight, the weight of the wet pod, weight of dry pods. Observations carried out from the age of 21 days with an interval of 14 days. Data results of observations were analyzed by analysis of variance followed by LSD test $5 \%$.

\section{1 . Plant height}

\section{Result and Discussion}

Table 1. Average Plant height ( $\mathrm{cm}$ ) at age 21 dap, 35 dap , 49 dap, DuetoInteractions Between the ApplicationConcentration Cow Biourineand Dosages ofSP-36 fertilizer .

\begin{tabular}{|l|l|l|l|}
\hline \multicolumn{1}{|c|}{ Treatment } & \multicolumn{2}{|c|}{ Days (dap) } \\
\cline { 2 - 4 } & \multicolumn{1}{|c|}{$\mathbf{2 1}$} & \multicolumn{1}{|c|}{$\mathbf{3 5}$} & \multicolumn{1}{|c|}{} \\
\hline Biourineconcentration 1:5 and without SP-36 fertilizer & $20,60 \mathrm{i}$ & $39,63 \mathrm{hi}$ & $38,70 \mathrm{i}$ \\
\hline Biourineconcentration 1:5 and without dose of 100 kg ha ${ }^{-1}$ SP-36 fertilizer & $22,83 \mathrm{bg}$ & $40,77 \mathrm{bi}$ & $39,47 \mathrm{hi}$ \\
\hline Biourineconcentration 1:5 andDoseof 125 kg ha ${ }^{-1}$ SP-36 fertilizer & $25,07 \mathrm{a}$ & $43,13 \mathrm{a}$ & $50,63 \mathrm{a}$ \\
\hline Biourineconcentration 1:10 and without SP-36 fertilizer & $21,80 \mathrm{ei}$ & $39,70 \mathrm{gi}$ & $41,63 \mathrm{f}$ \\
\hline Biourineconcentration 1:10 and Doseof 100 kg ha ${ }^{-1}$ SP-36 fertilizer & $21,60 \mathrm{fi}$ & $40,57 \mathrm{ci}$ & $43,27 \mathrm{e}$ \\
\hline Biourineconcentration 1:10 and Dose of 125 kg ha ${ }^{-1}$ SP-36 fertilizer & $20,67 \mathrm{hi}$ & $39,97 \mathrm{fi}$ & $45,67 \mathrm{~d}$ \\
\hline Withoutbiourineand without SP-36 fertilizer & $20,73 \mathrm{gi}$ & $40,17 \mathrm{di}$ & $47,40 \mathrm{e}$ \\
\hline Withoutbiourineand Dose of 100 kg ha ${ }^{-1}$ SP-36 fertilizer & $22,50 \mathrm{di}$ & $39,30 \mathrm{i}$ & $48,73 \mathrm{~b}$ \\
\hline Without biourineand Dose 125 kg ha ${ }^{-1}$ SP-36 fertilizer & $22,53 \mathrm{ci}$ & $40,07 \mathrm{ei}$ & $40,53 \mathrm{~g}$ \\
\hline BNT 5\% & 2,137 & 1,69 & 0,97 \\
\hline
\end{tabular}

Notes: Numbers followed by the same letter on each day have shown insignificant difference on LSD (Least Significant Difference) test of 5\%.

Dap :Days after planting

Observations plant height done at age 21 dap , 35 dap and 49 dap. The highest value obtained in the treatment of cattle biourine concentration 1:51 of water and fertilizers SP- $36125 \mathrm{~kg} \mathrm{ha}^{-1}$ ( B1P3) is at the age of 21 days after planting, plant height $25.07 \mathrm{~cm}$, age 35 dap , $43.13 \mathrm{~cm}$ and age of 49 dap, $50.63 \mathrm{~cm}$, Observations can be seen in Table 1 above .

\section{2 . Leaf Area Index}

Table 2. Mean leaf area index ( $\mathrm{cm} 2$ ) at age 21 dap , 35 dap , 49 dapDuetoInteractions Between the ApplicationConcentration Cow Biourineand Dosages of SP-36 fertilizer

\begin{tabular}{|c|c|c|c|}
\hline \multirow[t]{2}{*}{ Treatment } & \multicolumn{3}{|c|}{ Days (dap) } \\
\hline & 21 & 35 & 49 \\
\hline Biourineconcentration 1:5 and without SP-36 fertilizer & $0,33 \mathrm{i}$ & 0,62 hi & $0,64 \mathrm{i}$ \\
\hline Biourineconcentration 1:5 and Dose of $100 \mathrm{~kg} \mathrm{ha}^{-1} \mathrm{SP}-36$ fertilizer & $0,36 \mathrm{di}$ & $0,65 \mathrm{di}$ & $0,65 \mathrm{hi}$ \\
\hline Biourineconcentration 1:5 and Dose of $125 \mathrm{~kg} \mathrm{ha}^{-1} \mathrm{SP}-36$ fertilizer & $0,45 \mathrm{ab}$ & $0,72 \mathrm{a}$ & $0,79 \mathrm{ab}$ \\
\hline Biourineconcentration 1:10 and without SP-36 fertilizer & 0,33 hi & $0,61 \mathrm{i}$ & $0,71 \mathrm{f}$ \\
\hline Biourineconcentration 1:10 and Dose of $100 \mathrm{~kg} \mathrm{ha}^{-1} \mathrm{SP}-36$ fertilizer & 0,33 gi & $0,65 \mathrm{ci}$ & $0,73 \mathrm{e}$ \\
\hline Biourineconcentration 1:10 and Dose of $125 \mathrm{~kg} \mathrm{ha}^{-1} \mathrm{SP}-36$ fertilizer & $0,34 \mathrm{fi}$ & 0,62 gi & $0,77 \mathrm{~d}$ \\
\hline Withoutbiourineand without SP-36 fertilizer & 0,34 ei & 0,65 bi & $0,78 \mathrm{c}$ \\
\hline Withoutbiourineand Dose of $100 \mathrm{~kg} \mathrm{ha}^{-1} \mathrm{SP}-36$ fertilizer & $0,42 \mathrm{bd}$ & $0,62 \mathrm{fi}$ & $0,79 \mathrm{bc}$ \\
\hline Withoutbiourineand Dose of $125 \mathrm{~kg} \mathrm{ha}^{-1} \mathrm{SP}-36$ fertilizer & $0,37 \mathrm{ci}$ & 0,64 ei & $0,68 \mathrm{~g}$ \\
\hline BNT $5 \%$ & 0,069 & 0,050 & 0,006 \\
\hline
\end{tabular}

Notes: Numbers followed by the same letter on each day have shown insignificant difference on LSD (Least

Significant Difference) test of 5\%.

Dap :Days after planting

In table 2 can be seen the highest value on the leaf area index parameter is the concentration of biourine treatment B1P3 cow 1:5 L of water and fertilizers SP- $36125 \mathrm{~kg} \mathrm{ha}^{-1}$ at age of 21 dap of $0.45 \mathrm{~cm}^{2}$, at age of 35 dap, $0.72 \mathrm{~cm}^{2}$ and at age of 49 dap by $0.79 \mathrm{~cm}^{2}$. 
The Study of Concentration Cow Biourine and Dosage of SP-36 Fertilizeron Growth and ....

\subsection{Production Parameters}

Table 3. Average Plant Dry Weight ( g ) Weight Pods Wet ( g ), Dry pods Weight ( g ) Due to Interactions

Between the ApplicationConcentration Cow Biourine and Dosages of SP-36fertilizer

\begin{tabular}{|c|c|c|c|}
\hline Treatment & $\begin{array}{l}\text { The dry weight of } \\
\text { the plant }(\mathrm{g})\end{array}$ & $\begin{array}{l}\text { Heavy wet } \\
\operatorname{pods}(\mathrm{g})\end{array}$ & $\begin{array}{l}\text { Heavy } \\
\text { dry pods }\end{array}$ \\
\hline Biourineconcentration 1:5 and without SP-36 fertilizer & $23,17 \mathrm{fi}$ & $74,63 \mathrm{gi}$ & $38,67 \mathrm{ci}$ \\
\hline $\begin{array}{l}\text { Biourineconcentration 1:5 and dose of } 100 \mathrm{~kg} \mathrm{ha}^{-1} \\
\text { SP-36 fertilizer }\end{array}$ & 23,87 ei & $78,53 \mathrm{di}$ & $31,28 \mathrm{hi}$ \\
\hline Biourineconcentration 1:5 and dose of $125 \mathrm{~kg} \mathrm{ha}^{-1} \mathrm{SP}-36$ fertilizer & $28,97 \mathrm{a}$ & 99,00 ac & $50,06 \mathrm{ab}$ \\
\hline Biourineconcentration 1:10 and without SP-36 & $22,90 \mathrm{hi}$ & $83,73 \mathrm{bi}$ & $40,06 \mathrm{bi}$ \\
\hline $\begin{array}{l}\text { Biourineconcentration } 1: 10 \text { and dose of } 100 \mathrm{~kg} \mathrm{ha}^{-1} \text { SP-36 } \\
\text { fertilizer }\end{array}$ & $23,10 \mathrm{gi}$ & $70,70 \mathrm{hi}$ & $31,94 \mathrm{gi}$ \\
\hline $\begin{array}{l}\text { Biourineconcentration } 1: 10 \text { and dose of } 125 \mathrm{~kg} \mathrm{ha}^{-1} \mathrm{SP}-36 \\
\text { fertilizer }\end{array}$ & $23,97 \mathrm{di}$ & $64,73 \mathrm{i}$ & $24,94 \mathrm{i}$ \\
\hline withoutbiourineand without SP-36 fertilizer & $25,17 \mathrm{bi}$ & $75,27 \mathrm{fi}$ & $32,22 \mathrm{fi}$ \\
\hline withoutbiourineanddose of $100 \mathrm{~kg} \mathrm{ha}^{-1} \mathrm{SP}-36$ fertilizer & $22,80 \mathrm{i}$ & 76,93 ei & 33,50 ei \\
\hline withoutbiourineanddose of $125 \mathrm{~kg} \mathrm{ha}^{-1} \mathrm{SP}-36$ fertilizer & $24,17 \mathrm{ci}$ & $81,40 \mathrm{ci}$ & $34,83 \mathrm{di}$ \\
\hline BNT $5 \%$ & 2,97 & 18,17 & 11,20 \\
\hline
\end{tabular}

Notes: Numbers followed by the same letter on each day have shown insignificant difference on LSD (Least Significant Difference) test of $5 \%$.

Dap :Days after planting

Data obtained on the observation that the best value is obtained at treatment Biourine concentration of 1: 5 and a dose of $125 \mathrm{~kg} \mathrm{ha}^{-1} \mathrm{SP}-36$ fertilizer at all ages observation and observation parameters.

Plants need nutrients to grow and thrive. Nutrients needed by plants include macro nutrients $(\mathrm{C}, \mathrm{H}, \mathrm{O}$, $\mathrm{N}, \mathrm{P}, \mathrm{K}, \mathrm{Ca}, \mathrm{Mg}$ and $\mathrm{S}$ ) and micro nutrients (Fe, $\mathrm{Mn}, \mathrm{Zn}, \mathrm{Cu}, \mathrm{Bo}, \mathrm{Co}, \mathrm{Mo}, \mathrm{Na}, \mathrm{Cl}$, and $\mathrm{Si}$ ). In the vegetative phase, the nutrients in large quantities namely nitrogen, phosphate and potassium. Nitrogen is vital to the growth of the plants. Nitrogen serves as a regulator that controls the use of potassium, phosphate and other elements, if the lack of nutrients so plants will grow abnormally.

In biourine from manure and cow urine contains nutrients nitrogen is high, and therefore contributes to the growth of plant height, the higher the dose given, the better because other than as a fertilizer for plants, when applied to the ground, it will be able to improve the physical properties, chemical, and biological soil. The absorption of nutrients through the leaves generally enter through the stomata, in the leaves are stomata also called leaf mouth that can open and close mechanically and is governed by the so-called turgor pressure of cells cover. If turgor pressure increases, the stomata will open and when the turgor pressure decreases, the stomata will close(Qibtiyah, 2014).

Biourine derived from cow manure contains nutrients nitrogen are high, while nitrogen is a nutrient that has the effect of relatively rapid plant growth, plant will be bright green to dark when adequate nitrogen, nitrogen serves as the regulator for controlling the use of potassium, phosphorus and other elements, While the cow urine contains many growth hormones that contribute to plant growth. According to the crop nitrogen deficiency or shortage will grow stunted and root growth is inhibited. Of leaves will turn yellow or yellowishgreen and tends to fall. This is in line with Musnamar (2003) Award concentration biourine cows including organic fertilizer supplied contains macro elements such as $\mathrm{N}, \mathrm{P}, \mathrm{K}, \mathrm{Ca}, \mathrm{Mg}, \mathrm{S}$ also contains micro elements such as $\mathrm{Mn}, \mathrm{Zn}, \mathrm{Fe}, \mathrm{Cu}, \mathrm{Cl}$ many necessary by plants.

Nutrients second after $\mathrm{N}$ is causing critical growth of the plants in the field is phosphate $(\mathrm{P})$, deficiency of real P-uptake uptake consequences because other elements could be hampered. $\mathrm{P}$ nutrients play a role in the process of photosynthesis, the use of sugar and starch, as well as energy transfer.

Fertilizer $\mathrm{P}$ is the second after the $\mathrm{N}$ nutrient required by plants in considerable amounts. Availability of $\mathrm{P}$ in the soil is determined by soil parent material and the factors which influence such as soil reaction $(\mathrm{pH})$, levels of $\mathrm{Al}$ and Fe oxides, Ca levels, organic matter content, texture and land management (Kasno et al., 2006). Phosphorus plays an important role in various processes, such as photosynthesis, assimilation, and respiration. Phosphorus is a structural component of a molecule compounds transfer or energy ADP, ATP, NAD, NADH, and compounds genetic information system of DNA and RNA. P element plays a role in the growth of plants (stems, roots, branches, and leaves). Phosphate needed by plants for the formation of cells in tissues of roots and shoots growing and strengthening the trunk, so it does not easily fall in natural ecosystems (Aleel, 2008). P nutrients play a role in the process of photosynthesis, the use of sugar and starch, as well as energy transfer. P deficiency results in slow plant growth, weak and stunted so that the plant can not produce high (Sumarni et al., 2012). The usefulness of phosphate fertilizers are encouraging early root growth, the growth of flowers and seeds, increase the percentage of flower formation into seeds, add plants resistance to pests and diseases, and improve the structure of soil nutrients (Marzuki, 2007). 
Phosphorus fertilizer use hardly lose much compared with the use of nitrogen fertilizer. However, a fixed amount of $\mathrm{P}$ greater than that lost through harvest. Based on this reality, the supposed number of $\mathrm{P}$ remaining in the ground are taken into account in the means of fertilization, because phosphorus $(\mathrm{P})$ including macro nutrients vital for plant growth (Ismail, 2013). Leaf area index affects the leaf area plant. This is in line with Yuliarta (2013), that auxin initiates cell elongation by affecting cell wall loosening or flexing. Auxin stimulate specific proteins in the plasma membrane of plant cells.

The leaves are part of the plant that has a very important function, because all of the other functions depending on the leaf directlt or indirectly. From photosynthesis in the leaves will produce usable energy for growth and development of the leaves. The number of leaves will affect the amount of assimilates produced, which in turn also affect the formation of leaves and other plant organs.

According Ma'sumah (2002) leaf plays a very important for a plant productivity. The number and size of leaves is affected by genotype and environmental factors. Environmental factors were influential factor is soil, water, light and nutrients.

According Marsono \& Sigit (2005) fertilizer basically aims to add some nutrients, especially macro and micro nutrients that are needed by plants. The role of nutrients is to help stimulating the development of all plants so that the plants will grow faster, the absorption of nutrients is relatively large. The functions of Sp-36 fertilizer for plants, namely, accelerate root growth in seedbed, triggers and strengthens the growth of adult plants in general, increase fruit production. This is in accordance with the opinion (Sutedjo and Sapoetra, 2005) of $\mathrm{P}$ is a cell nucleating agent.

In biourine there are many beneficial bacteria, one of which is Bacillus sp. Bacillus sp. is a bacteria that can produce phytohormones that can affect the growth of plants, either directly or indirectly. Fitohormon indirectly inhibits the activity of bacterial pathogens in plants, while the direct effect is to increase petumbuhan fitohormon the plant and can be useful as a facilitator of plants in the absorption of some nutrients from the place where they are grown. Bassilus sp bacteria is a bacteria that is able to provide nutrient phosphate. This is done by through leaching of nutrients phosphorus was previously a form that is not readily available to plants, into nutrients phosphorus readily usable by plants, so the plants do not lack the element of phosphate (Leskona et al., 2013).

Nutrients are dissolved in water and sprayed on plants can be absorbed by plants through the stomata, as it allows the fertilizer enter through the gap when the stomata open. Fertilization through leaves during pod filling stage can increase soybean pod filling. Provision of nutrients through the leaves will address the shortage of nutrients in the leaves as a result retranslokasi nutrients from leaves to seeds that are formed (Judge et al, 2004).

Phosphorus stimulates the formation of flowers, fruits, and seeds. Even able to increase fruit ripening and make seeds become more spirited. Plant P deficiency can be observed visually, that leaves older leaves will be purple or reddish. Another symptom is neksrosis (tissue death) on the edge or blade and petiole, followed by weakening the stems and roots of plants (Sian, 2008).

SP-36 fertilizer is a fertilizer P in the form of super phosphate which contains 36\% P2O5 which is in the ground is not immediately available and partially fixed. Advantages of the SP-36 fertilizer can stimulate early seedling growth of plants, the formation of flowers, fruits and seeds even able to accelerate the ripening of fruit and seeds become more spirited. P fertilization is needed by plants growing in cold regions, plants with roots that slow or stunted (Novizan, 2005). In the SP-36 fertilizer contains 36\% P2O5 which encourages early root growth, the growth of flowers and seeds, increase the percentage of flower formation into seeds, add plants resistance to pests and diseases, and improve the structure of soil nutrients (Marzuki 2007).

$P$ fertilization effect on yield and nutrient content $P$. The function of phosphorus in the plant that can accelerate the growth of seedling roots, can accelerate and strengthen the growth of young plants into mature plants, accelerate flowering and ripening fruits and seeds and to increase grain production. Phosphorus for plants can also fix generative growth, especially the formation of flowers, fruits, and seeds. If a good vegetative growth, photosynthesis produced more and more, this led to the plant's ability to form the generative organs is increasing (Sutedjo, 2002).

Rosmarkam and Yuwono (2002) suggested that the plant nutrients in the form of gases such as SO2, $\mathrm{NH} 3$ and NO2, can enter through the leaf through the stomata. Fertilizer application through the roots feared would be lost due to evaporate or undergo fixation in the soil before it could be absorbed by plant roots. Meanwhile, according to Lingga and Marsono (2004), the absorption of nutrients through the leaves generally enter through the stomata, in the leaves are stomata also called leaf mouth that can open and close mechanically and is governed by the so-called turgor pressure of cells cover. If turgor pressure increases, the stomata will open and when the turgor pressure decreases, the stomata will close.

According Selpiana (2012) which states that, plant height relates to the number of leaves, as leaves lie in the book stems of plants, so the greater plant height, leaf area and number of leaves, then wet weight will increase weight of wet plant reflects an increase of protoplasm, these things happen due to the size and number 
of cells increases. Protoplasm growth takes place through metabolism events where water, carbon dioxide, and inorganic salts converted into reserves of food by the process of photosynthesis. Followed by Sumarsono (2007), food storage plant will be used in the metabolic process that generates energy for plant growth. Provision of fertilizer from organic matter can increase the height, number and area of leaves of soybean plants thus affecting plant fresh weight.

Organic and inorganic fertilizer application on the plant will increase plant growth. This is because if the nutrients that plants need adequate then, the rate of plant growth will be high so that favorable conditions for plants and as a result will ultimately obtained maximum crop production. said that phosphorus for plants can also improve the generative growth, especially the formation of flowers, fruits, and seeds. If a good vegetative growth, photosynthesis produced more and more, this led to the plant's ability to form the generative organs is increasing.

\section{Conclusion}

The results of the research study biourine concentration of cattle and SP- 36 fertilizer application on the growth and yield of soybean ( Glicine max ( L. ) Merrill ) concluded :

a. In the vegetative growth parameters of interaction between the effect of the concentration of cattle and fertilizers biourine SP- 36 on the parameters plant height and leaf area on all observations.

b. In parameter generative plant dry weight, the weight of the wet pod, weight of dry pods, showed an interaction between cattle and fertilizer biourine SP - 36 .

c. Best treatment combination contained in cow biourine concentration 1:51 of water and fertilizer SP - 36 $125 \mathrm{~kg} \mathrm{ha}^{-1}$

\section{References}

[1] Adisarwanto. 2008. BudidayakedelaiTropika. PenebarSwadaya. Jakarta.

[2] Aleel, K.G. 2008. Phosphate Accumulation in Plant: Signaling. Plant Physiol. 148:3-5.

[3] Hakim, A, S.S.R. Samosir, S. Ala. 2004.PengolahanMulsaJeramiPadidanPemupukanLewatDaundanPengaruhnyaterhadapProduksiKedelai di LahanSawah.JurnalSains\&Teknologi.

[4] Ismail, F 2013.PengaruhPupukFosforTerhadapPertumbuhanJagungHibrida di KelurahanDulomo Utara Kecamatan Kota Utara Kota Gorontalo.Skripsi.Fakultaspertanian.Gorontalo

[5] Kasno. A, D. Setyorini, dan E. Tuberkih. 2006. PengaruhpemupukanFosfatterhadapProduktivitas Tanah InceptisoldanUltisol. ISSN 1411 - 0067 jurnalImu-IlmuPertanianIndonesia. Volume 8, No. 2, 2006, Hlm. 91 - 98

[6] Ma'sumah. 2002. Pengaruhmacam media tanamdankonsentrasipupukorganikcairterhadappertumbuhandanhasilbuahtanamantomat (LycopersicumesculentumMill.) secarahidroponik. Skripsi S1 FakultasPertanian UNS Surakarta.

[7] Marsono\&Sigit. 2005. PupukAkar. PenebarSwadaya. Jakarta.

[8] Marzuki, R. 2007. BertanamKacang Tanah. PenebarSwadaya. Jakarta.

[9] Musmanar, I. 2003. PupukOrganikPadat. Jakarta: PenebarSwadaya

[10] Novizan.2005. PetunjukPemupukan yang Efektif.AgromediaPustaka. Jakarta.

[11] Qibtiyah, Mariyatul. $2014 . \quad$ KajianPengaruhWaktuPemberiandanDosisBio-urine TerhadapPertumbuhandanProduksiTanamanPadi(Oryza Sativa L).Tesis.ProgramStudillmuTanaman, Program Pascasarjana, FakultasPertanian, UniversitasBrawijaya, Malang.

[12] Sianturi D. 2008

UjiKandunganFosfatSebagai

$\mathrm{P} 2 \mathrm{O} 5$ DalamBerbagaiMerekPupukFosfatKomersilsecarasSpektrofotometri.Skripsi.Medan :Universitas Sumatera Utara.

[13] Sutari, N. W. S. 2010. PengujianKualitasBio-urine HasilFermentasidenganMikroba yang BerasaldariBahanTanamanTerhadapPertumbuhandanHasilTanamanSawiHijau (Brassica junceaL.).Tesis. Program StudiBioteknologiPertanian, Program Pascasarjana, FakultasPertanian, UniversitasUdayana, Denpasar.

[14] Sutedjo, M. M. \&Sapoetra, S. 2005. Pengantarllmu Tanah. RinekaCipta. Jakarta.

[15] Syekhfani. 1994. Hara-Air-Tanah-Tanaman. Jurusan Tanah. FakultasPertanian. UniversitasBrawijaya. Malang 